\title{
The effect of rearing media salinity on survival, growth, and blood glucose of juvenile mahseer (Tor soro)
}

\author{
Yohanna R. Widyastuti ${ }^{1, *}$, Eri Setiadi ${ }^{1}$, Yosmaniar $^{1}$ \\ ${ }^{1}$ Research Institute for Freshwater Aquaculture and Fisheries Extension Bogor, West Java, Indonesia
}

\begin{abstract}
Optimization of Mahseer (Tor soro) rearing water media supports seed mass production. This study aims to obtain optimal salinity for production performance in rearing Tor soro. The research was conducted at the Wet Laboratory of the Research Institute for Freshwater Aquaculture and Fisheries Extension Bogor. The test fish was Tor soro with 1-2 cm in body length. Experimental design using completely randomized design with four treatments of salinity: $0,2,4$, and 6 ppt and three replications each. Twelve aquarium glasses with a volume of $50 \mathrm{~L}$ each as experiment containers and stocking density was one fish/ L. Tubifex worms were fed at satiation, fish were reared within 40 days. The observed parameters were survival rate, absolute growth and length, specific weight growth rate, blood glucose level, and osmolarity. Data analysis using ANOVA test and Duncan for post hoc test. Water quality parameters, blood glucose, and osmolarity were analyzed descriptively. The results showed that two ppt of media salinity is optimal for the rearing of Tor soro to obtain the maximum of production performance (survival rate, absolute growth, and length, specific growth rate) and the best condition for blood glucose and level osmotic work.
\end{abstract}

\section{Introduction}

Mahseer (Tor soro) fish is a freshwater species commodity that can be cultured due to high economic value for local market and export [1]. Recently, the population of mahseer fish in the wild has been decreased caused of overfishing and habitat destruction [2]. Although seed production has successfully been produced, it is still unstable due to some factors. Therefore, mass seed production has to be increased through environmental manipulation of rearing media, such as applying salinity level to optimize production.

Salinity is one of the water quality parameters that play an important role in aquatic organisms' physiological, growth, and survival [3]. Salinity is correlated to the osmoregulation of organisms. Osmoregulation manages the balancing between the water environment and ionic in the body via the process of osmotic pressure [4]. Some of the salinity levels in rearing media had been applied, such as on seed production of Pangasiid catfish (Pangasius hypophthalamus) cultured in 7 ppt which can reach $100 \%$ of survival,

\footnotetext{
*Corresponding author: yrwid@yahoo.com
} 
and the specific growth rate (SGR) is $0,54 \pm 0,28 \%$ [5], Synodontis catfish cultured in $4 \mathrm{ppt}$ can also reach the $100 \%$ survival and $2,0 \pm 0,31 \%$ in SGR [6], the optimal production of climbing perch rearing at three ppt) [7], tambaqui (Colosoma macropomum) in 6 ppt [8], bala sark (Balantiochellos melanopterus) in 3 ppt [9], tilapia in 3 ppt [10], tinfoil barb (Babonymus schwanennfeldii) in 3 ppt [4], and sand goby (Oxyeleotris marmoratus) also in 3 ppt [11].

Blood glucose levels are a source of energy and have an important factor for the organism. Fish blood glucose can be used as a biomarker against the bad physiological condition. In stressful conditions by the poor environment, fish experience a primary and secondary response. The volume of blood in fish ranges from 1.5-3 \% of body weight. Normal fish blood glucose levels contain 40-90 mg/dl. Fish have different blood glucose levels depending on their size and activity [12]. Furthermore, [13] wrote blood glucose levels in elver were $94.33 \mathrm{mg} / \mathrm{dl}$. The abnormality of fish blood glucose causes disturbed life and can even lead to death. Salinity affects fish hormonal activity.

In the primary response, fish releases stress hormones, namely cortisol, adrenaline, and epinephrine, into the bloodstream through the endocrine system. This process is a change in state by the Central Nervous System (CNS). At the same time, the secondary response occurs due to the release of stress hormones that cause changes in blood and chemical tissues, such as increased blood glucose levels in fish [14].

Mahseer (T. soro) suggests that the osmotic pressure of internal body fluid is higher than that of external body fluid as the same as another fish. To balance osmotic pressure must be arranged between in and out of body fluid via the osmoregulation process [15]. Techniques for manipulating culture media through different salinity levels will improve energy efficiency in the osmoregulation process. Such conditions can increase survival and growth. The study of salinity's effect on the survival and growth of mahseer has not been informed yet. Thus, optimal salinity plays an important role in terms of productivity. The research aimed to determine the optimal salinity level for mahseer, $T$. soro juvenile rearing that was influenced to survival, growth, and blood glucose.

\section{Materials and methods}

The research was conducted at Research Institute for Freshwater Aquaculture and Fisheries Extension, West Java, Bogor. Water quality parameters were analyzed in the Water Quality Laboratory at Research Station for Environment Technology and Toxicology freshwater Aquaculture, Bogor. Blood glucose and osmolarity were analyzed in Fish Nutrition Laboratory at Faculty of Fisheries, Bogor Agricultural University.

The treatment of this research was salinity level, i.e., A) 0 ppt; B) $2 \mathrm{ppt}$; C) 4 ppt; and

D) $6 \mathrm{ppt}$ with three replicates each. To make the salinity level follow the procedure [11]:

$$
\mathrm{Va} . \mathrm{Na}=\mathrm{V} 1 . \mathrm{N} 1+\mathrm{V} 2 . \mathrm{N} 2
$$

\footnotetext{
$\mathrm{Va}=$ the final water volume than expected (L)

$\mathrm{Na}=$ the final salinity concentration than expected (ppt)

$\mathrm{V} 1=$ seawater volume diluted by freshwater (L)

$\mathrm{N} 1=$ Salinity level of seawater that diluted by freshwater (ppt)

$\mathrm{V} 2=$ Addition of freshwater to seawater $(\mathrm{L})$

$\mathrm{N} 2=$ Salinity level of freshwater that diluted by seawater (ppt)
}

Fish juveniles with 1-2 cm total length were used, and stocking density was one fish/L. Twelve aquariums with a water volume of $50 \mathrm{~L}$ each were used. Each aquarium was completed by aeration. A juvenile was fed tubifex worm until at satiation and given three 
times a day. Fish juveniles were reared for up to 40 days. For measuring the length and weight, ten fish were sampled every ten days. Water quality parameters such as $\mathrm{pH}$, temperature, and DO were measured by using digital tools. Nitrite, nitrate, and TAN (ammonia) were analyzed in the laboratory based on a spectrophotometer. Salinity was measured using a refractometer.

The calculations of survival rate, absolute growth, and weight followed [16], specific growth rate (SGR) [17], Glucose of body liquid [18], and osmotic work rate) [19]. All data were analyzed using one-way ANOVA. If there was a significant difference, then tested Duncan test by SPSS ver. 16.0 software while water quality parameters were analyzed descriptively, i.e., temperature, $\mathrm{pH}, \mathrm{DO}$, nitrite, nitrate, and ammonia.

\section{Results}

\subsection{Survival rate}

Salinity has influenced survival rate $(\mathrm{P}<0.05)$ where the fish reared at a salinity of $2 \mathrm{ppt}$ $(97.3 \pm 0.58 \%)$ was the highest, followed by four ppt $(87.3 \pm 0.88 \%), 0$ ppt $(79.3 \pm 3.62 \%)$, and six ppt (54.0 $\pm 1.07 \%)$ (Fig. 1).

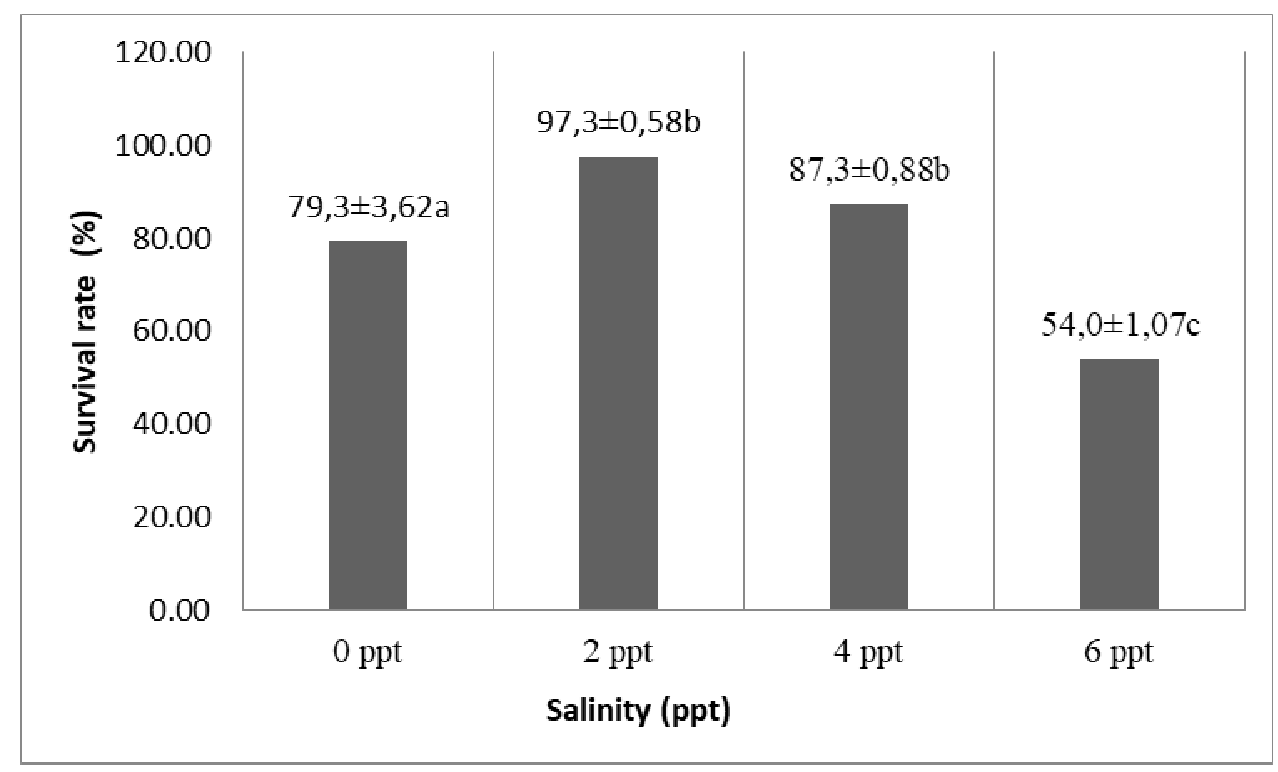

Fig. 1. The survival rate of mahseer on the treatment of salinity $0,2,4,6 \mathrm{ppt}$.

\subsection{Absolute weight growth}

The result of the absolute weight of mahseer fish in all treatments is shown in Figure 2. The absolute weight of fish $(\mathrm{g})$ at treatment $0 \mathrm{ppt}, 2 \mathrm{ppt}, 4 \mathrm{ppt}$ and $6 \mathrm{ppt}$ respectively is $0.95 \pm 0.26 ; 1.80 \pm 0.37 ; 0.95 \pm 0.04 ; 0.67 \pm 0.10 \mathrm{~g}$. The highest absolute weight growth rate obtained from salinity treatment was two ppt which is $1.80 \pm 0.37 \mathrm{~g}$. 


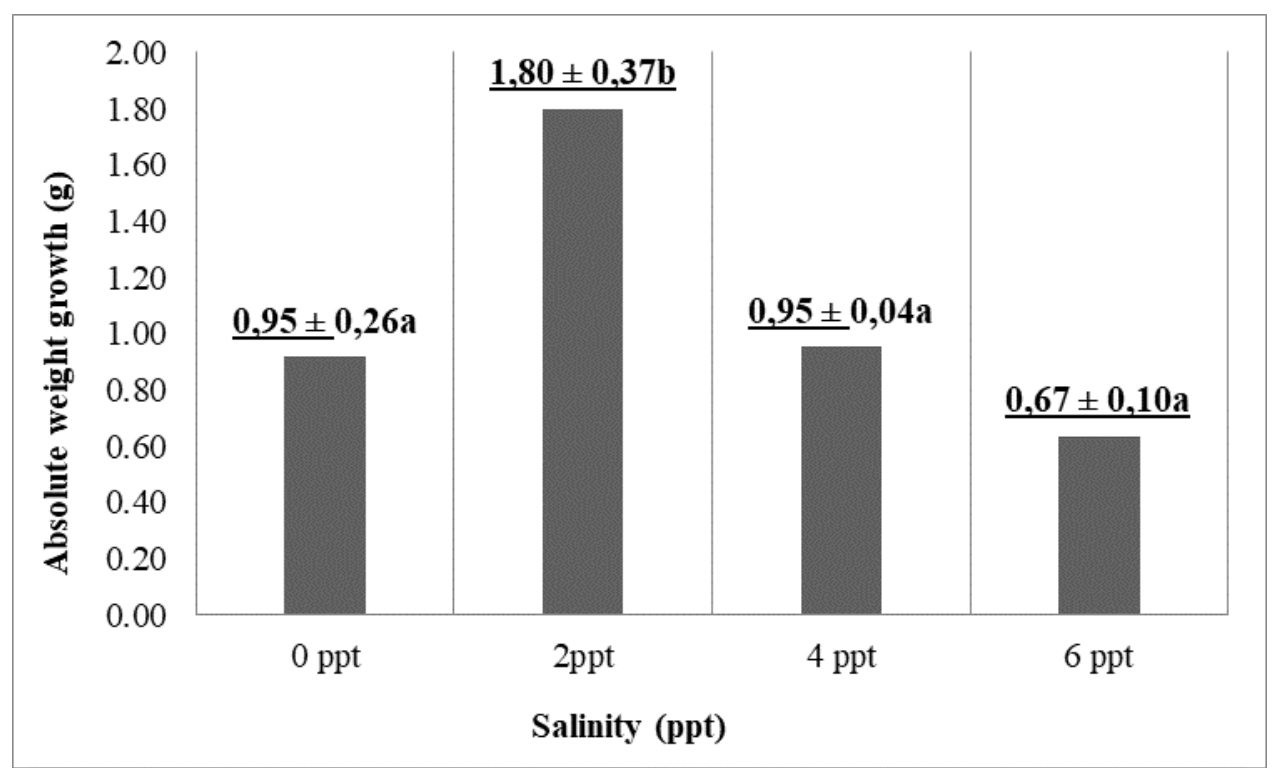

Fig. 2. Absolute weight growth of mahseer on the salinity of 0, 2, 4, 6 ppt.

\subsection{Absolute length growth}

The result of an absolute length growth measurement is shown in Figure 3. The absolute length of fish $(\mathrm{cm})$ on treatment $0,2,4$, and 6 ppt is 2,$63 ; 2,00 ; 1,60$ dan $1,45 \mathrm{~cm}$. Treatment 2 has a significantly different result with the treatment of 0 ppt and six ppt $(p<0.05)$, but it does not differ from the treatment of $4 \mathrm{ppt}(\mathrm{p}>0.05)$.

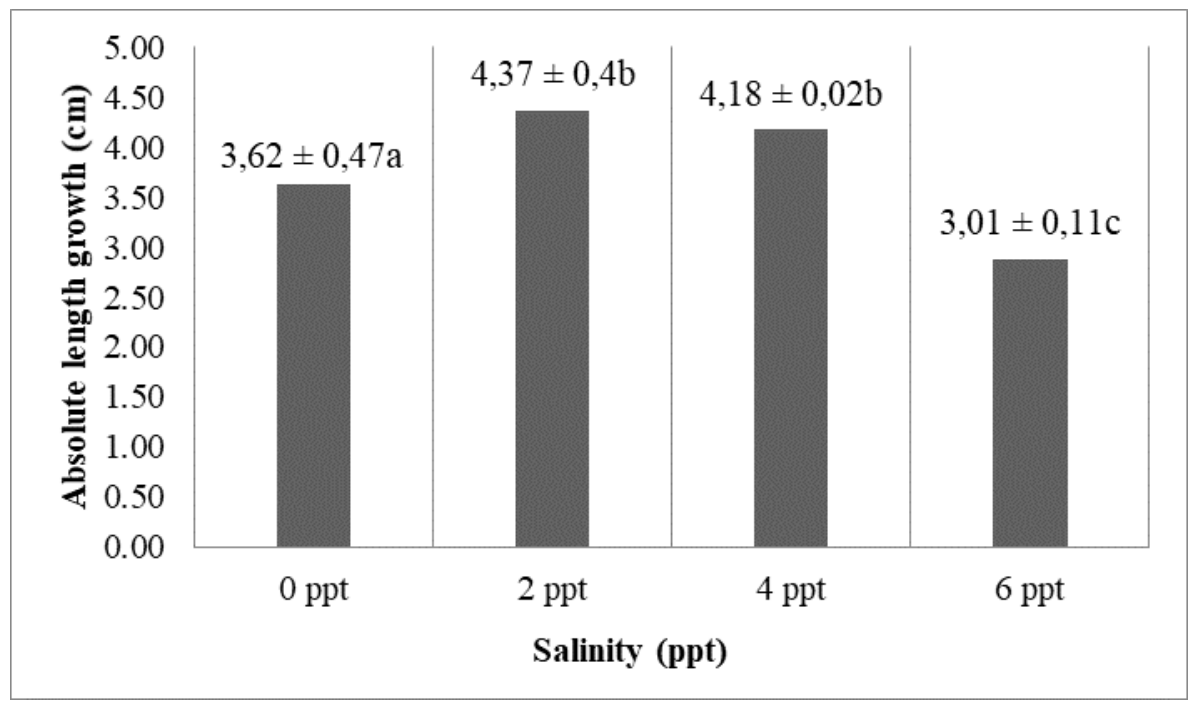

Fig. 3. Absolute length growth of mahseer on the salinity of 0, 2, 4, 6 ppt. 


\subsection{Specific growth rate}

The specific growth rate of mahseer fry weight in treatments of $0,2,4$, and 6 ppt respectively is $2,42 \pm 0.20 \% ; 4.34 \pm 0.15 \% ; 2.30 \pm 0.62 \% ; 1.30 \pm 0.48 \%$ (Figure 4 ). The growth rate of specific weights differs between treatments $(\mathrm{p}<0.05)$.

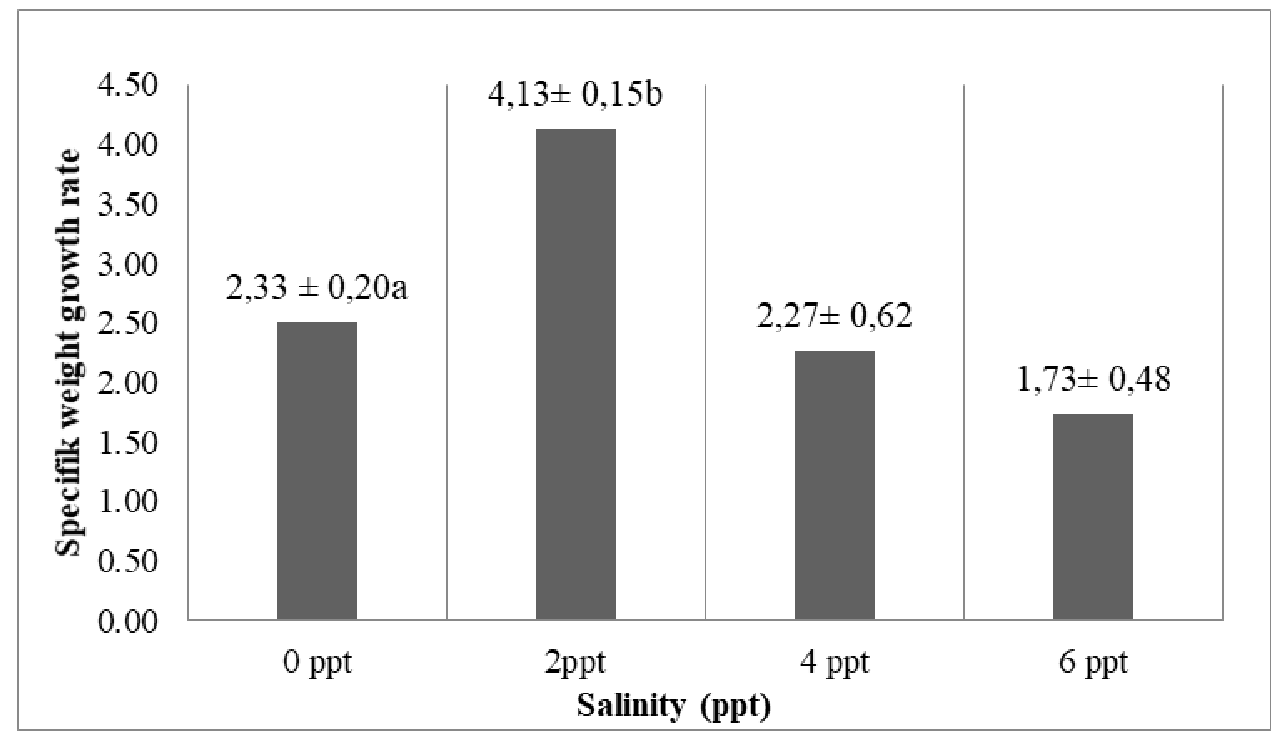

Fig. 4. The specific weight growth rate of mahseer on the treatment of salinity $0,2,4,6 \mathrm{ppt}$.

\subsection{Blood glucose of body liquid and Osmotic Work Rate (OWR)}

The result of the blood glucose values of body fluids and osmotic work rate in each treatment is demonstrated in Table 1. The lowest blood glucose content of body fluids is from the two ppt treatment, which is $0.09 \pm 0.002 \mathrm{mg} / 100 \mathrm{ml}$, and the highest of the six ppt treatment is $0.83 \pm 0.02 \mathrm{mg} / 100 \mathrm{ml}$. The Osmotic Work Rate value of each treatment can be seen in Table 1. The lowest level of osmotic work value obtained from salinity treatment two ppt is $0.23 \pm 0.005 \mathrm{~kg} / \mathrm{H} 2 \mathrm{O}$, and the highest of the six ppt treatment is $1.26 \pm 0.15$ $(\mathrm{p}<0.05)$.

Table 1. The results of blood plasma glucose measurements and osmolarity.

\begin{tabular}{ccc}
\hline Treatments & $\begin{array}{c}\text { Blood glucose body liquid } \\
\left(\mathrm{mg}^{-1} 100 \mathrm{ml}\right)\end{array}$ & $\begin{array}{c}\text { Level of osmotic work } \\
(\mathrm{kg} \mathrm{H} 2 \mathrm{O})\end{array}$ \\
\hline 0 & $0,62 \pm 0,011^{\mathrm{a}}$ & $0.411 \pm 0,12^{\mathrm{a}}$ \\
$2 \mathrm{ppt}$ & $0,09 \pm 0,002^{\mathrm{b}}$ & $0.23 \pm 0,005^{\mathrm{b}}$ \\
$4 \mathrm{ppt}$ & $0,29 \pm 0,01^{\mathrm{c}}$ & $0.65 \pm 0,007^{\mathrm{c}}$ \\
$6 \mathrm{ppt}$ & $0,83 \pm 0,02^{\mathrm{d}}$ & $1.26 \pm 0,15^{\mathrm{d}}$ \\
\hline
\end{tabular}

Noted: Superscript letters behind different standard deviations show significant differences $(p<0.05)$

\subsection{Water quality parameters}

The results of measuring water quality during this study are presented in Table 2 below. 
Table 2. The range values of water quality parameters in the treatment of salinity $0,2,4$, and 6 ppt during the experiment.

\begin{tabular}{|c|c|c|c|c|c|}
\hline \multirow[t]{2}{*}{ Parameters } & \multicolumn{4}{|c|}{ Salinity treatments (ppt) } & \multirow[t]{2}{*}{$\begin{array}{c}\text { Recommendation } \\
{[33]}\end{array}$} \\
\hline & 0 & 2 & 4 & 6 & \\
\hline $\mathrm{pH}$ & $5,9-6,2$ & $6,85-6,2$ & $7,0-7,4$ & $7,6-7,8$ & $6-9$ \\
\hline $\begin{array}{l}\text { Dissolve oxygen } \\
(\mathrm{mg} / \mathrm{l})\end{array}$ & $4,0-4,4,4$ & $4,0 .-4,2$ & $3,91-4,2$ & $3,80-4,0$ & $>3$ \\
\hline $\begin{array}{l}\text { Temperature } \\
\left({ }^{\circ} \mathrm{C}\right)\end{array}$ & $27,8-29,8$ & $28,50-30,7$ & $28,2-29,2$ & $29,24-30,0$ & $25-32$ \\
\hline Nitrite $(\mathrm{mg} / \mathrm{l})$ & $0,01-0,10$ & $0,015-0,02$ & $0,01-0,02$ & $0,02-0,03$ & $<0,1$ \\
\hline$T A N(m g / l)$ & $0,01-0,1$ & $0,01-0,15$ & $0,1-0,17$ & $0,1-0,2$ & $<0,1$ \\
\hline
\end{tabular}

\section{Discussion}

The highest survival rate of fish reared at two ppt is on the iso-osmotic conditions. This condition means having the same or equal osmotic pressure. The body and organ cells function of fish will work properly when it's in the balance condition between internal osmotic and external osmotic [20]. The hypo-osmotic condition was found at six ppt treatment and had the lowest survival rate. Hypo-osmotic conditions appeared where external environment concentration was higher than that of the internal fish body. Therefore the water from the external will enter through the fish body. The effect boosts the fish to die, which causes the dilution in the liquid of the fish body [21]. Such condition will affect the ions composition in the liquid in the fish body) [22]. According to [23], water salinity will affect the regulation of internal ions that directly involve energy for the active transport of ions to maintain the internal environment. In these conditions, the mahseer fish lacks the ability to a transaction with osmotic pressure stress. So that it is understood the lowest survival rate occurs in the treatment of 6 ppt.

Some hatcheries reported that freshwater fish species have different optimal water salinity. The optimal salinity of Balashak fish is three ppt with a survival rate of $98.67 \%$ [9]. The result [24] showed that the carp juvenile maintained in 3 ppt salinity has the highest survival $(93.33 \%)$. Furthermore, the results of [11], showing at salinity three ppt, yielded the highest fish survival of sand goby (O. marmoratus).

Mahseer likes other freshwater fish, which have an osmotic pressure body fluids greater than osmotic pressure in the environment. However, the salts in the body tend to come out while water tends to enter the body, diffusing through the body's surface. If this is not controlled or balanced, it will lead to the loss of salts in the body, resulting in death in fish [25]. Therefore, the energy used to adjust the osmotic pressure of the fish's body to its environment is smaller than salinity treatment 0,4 , and 6 ppt. Furthermore, the energy used for the growth of his body weight becomes greater.

Fish reared in an iso-osmotic environment used the energy from the feed only slightly for the osmoregulation process. The growth results show an absolute length growth is greater than absolute weight growth during this study. This value indicates that the growth in the fish length is faster than the growth of weight, also known as negative allometric growth [26]; [27]. Based on [28], hormones insulin-like growth factor 1, gonadotropin, cortisol, and thyroid take a role in fish osmotic regulation. The specific growth rate of individual weight is the highest of the two ppt salinity and the lowest of the six ppt treatment. The environment iso-osmotic (salinity two ppt) is suspected the reason for this. The energy used for the osmoregulation process becomes less. The remaining energy converts to be used for growth. 
On the contrary, on salinity treatment of $6 \mathrm{ppt}$, the energy used for osmoregulation is greater than the energy used for its growth. According to [15], the more differences in osmosis pressure between the body and the fish environment, the extra metabolic energy needed to osmoregulate as an adaptation to the environment. Fish will reduce involvement stress when in conditions of the environment's osmotic pressure is higher than the osmotic pressure of the body. These conditions will decrease appetite and subsequently affect the rate of fish growth. In this study, salinity treatment of $6 \mathrm{ppt}$ resulting minimum specific growth rate and the lowest absolute weight. It was due to that the energy from the feed is mostly used to perform the body osmoregulation process [29]. Common carp found high SGR when persevering 0 to $2.5 \mathrm{ppt}$ of salinity [30]

The low blood glucose content of body liquid in 2 ppt salinity shows that mahseer juvenile involvement the lowest stress compared to other salinity. The highest value of blood glucose content of body liquid from $6 \mathrm{ppt}$ salinity indicates that the fish experience the most stress. According to [21], blood glucose parameters of body liquid can be used to evaluate the physiological response of stress in fish.

That one of the stress causes is due to environmental changes such as water quality [31]. The salinity treatment results in hyperglycemia (increase in glucose in body fluids) and will follow health conditions, survival, and growth.

The lowest osmotic work rate (OWR) of the two ppt salinity indicates that the osmotic body liquid tends to close with the osmotic of fish environment, and it's called iso-osmotic. Thus, the fish in iso-osmotic conditions will be within normal physiological functions while energy for osmoregulation is low.

This case is in line with the highest production performance value of specific growth rate and survival rate. Highest survival rate obtained by 2 ppt salinity treatment. Feed digestion process becomes more efficient when the osmotic work rate of the fish body is balanced with its environment [32]. This condition is inversely when compared to fish which is kept at unbalanced osmolarity. Furthermore, [20] suggests that the body's cells are in ideal condition in osmolarity conditions or close to iso-osmotic. All body physiological processes drive normally.

Water quality parameters obtained during this study are in the range of quality standards according to [33], namely $\mathrm{pH}$, Dissolved oxygen, temperature, and nitrite. This indicates that salinity does not affect water quality parameters.

The ammonia content in salinity of 4 and 6 has slightly exceeded the standard by [33] compared to the treatment of no salinity and two ppt. According to [33], water with higher salinity led to increased solubility of ammonia content.

\section{Conclusion}

Water salinity of $2 \mathrm{ppt}$ is an optimum level for rearing Mahseer (Tor soro), producing the highest production performance, namely survival rate, absolute growth and length, specific growth rate, and lowest liquid body blood glucose well as level osmotic work rate.

\section{Acknowledgement}

Appreciation and gratitude conveyed to DR. Ani Widiyati (may she rest in peace with God Almighty) for her cooperation and suggestions. Thank you to the staff of Genetic and population Installation who have helped with the research. 


\section{References}

1. J. Subagja, D. Radona, J. Ris. Akuak. 12, 1 (2017)

2. R. Gustiano, E. K. Kontara, H. Wahyuningsih, J. Subagja, S. Asih, A. Saputra, Commun. Agric. Appl. Biol. 78, 4 (2013)

3. D. Rachmawati, J. Hutabarat, S. Anggora, J. Ilmu Kelaut. 17, 3 (2012)

4. S. K. Nurjanah, Undergraduate Thesis, Bogor (ID): IPB University (2014)

5. M. Fitrani, Postgraduate Thesis, Bogor (ID): IPB University (2009)

6. R.T. Gustino, Undergraduate Thesis, Bogor (ID): IPB University (2011)

7. F. Nahar, W. Haque, D. Ahsan, M.G. Mustafa, J. Biol. Sci. 25, 1 (2016)

8. D. Djokosetiyanto, A.R. Wulandari, O. Carman, J. FISH. Sci. 10, 2 (2008)

9. T. Kadarini, Postgraduate Thesis, Bogor (ID): IPB University (2009)

10. A.S. Fitri, JAM Tech. 1, 1 (2012)

11. I. Ardi, E. Setiadi, A.H. Kristanto, A.Widiyati, J. Ris. Akuak. 11, 4 (2016)

12. W.R Driedzic, K.A. Clow, C.E. Short, J. Exp. Biol. 216, 3 (2013)

13. L. Fekri, R. Affandi, M.F. Rahardjo, T. Budiardi, C. P. H. Simanjuntak, Warta Iktiologi 19, 2 (2019)

14. K. V. Cook, C. M. O’Connor, S. H. McConnachie, K. M. Gilmour, S.J. Cooke, CBP. 161, 3 (2012)

15. Y. Fujaya, Fish physiology (in Bahasa Indonesia) (Rineka Cipta, Jakarta, 2004)

16. M.I. Effendie, Fisheries biology (in Bahasa Indonesia) (Yayasan Pustaka Nusantara, Yogyakarta, 1997)

17. E.A. Huisman, The principles of fish culture production (Wageningen Agricultural Netherland University Press, Wageningen, 1987)

18. S.C. Eames, L H Philipson, V.E. Prince, M. D. Kinke, J. Vis. Exp. 7, 2 (2010)

19. S. Anggoro, Postgraduate Thesis, Bogor (ID): IPB University (1992)

20. M.B. Syakirin, PENA Akuatika 1,1 (2007)

21. S. Kuçuk, Afr. J. Biotechnol. 12, 16 (2013)

22. D. Hasbullah, M. Y. Karim, Zainuddin, D. Trijuno, AACL Bioflux. 11, 3 (2018)

23. M.Y. Karim, J. of Fish. Sci. 10, 1 (2008)

24. M. S. Al-khshali, Postgraduate Thesis, Baghdad (IQ): University of Baghdad (2011)

25. R. Affandi, U.M Tang, Aquatic physiology (in Bahasa Indonesia) (Intimedia, Malang, 2017)

26. I. Kusmini, R. Gustiano, F.P. Putri, J. Berita Biol. 13, 2 (2014)

27. A. Widiyati, B.N. Asyiah, T.H.Prihadi, D. Puspaningsih, E3S Web of Conf. 47, 02003 (2018)

28. S. Mc Cormick, AMER. ZOOL. 41, 781-794 (2001)

29. J.F. Arjona, L.V. Chacoff, I.R. Jarabo, O. Goncalves, I. Pascoa, P. Maria, M.D. Rio, J.M. Mancera, J. Aquaculture, 287 (2009)

30. J.Q. Wang, H. Lui, H. Po, L. Fan, J. Aquaculture, 146 (1997)

31. B.A. Barton, R.E. Peter, C.R. Paulencu, Can. J. Fish. Aquat. Sci. 37, 5 (1980)

32. G.J. Partridge, G.I. Jenkins, J.Aquaculture, 210 (2002)

33. C.E. Boyd, Water quality management for pond fish culture (Elsevier Publishing Company, Amsterdam, 1990) 